\title{
Quality of Antenatal Care at Urban and Rural Puskesmas (Public Health Center) in Jeneponto Regency
}

\author{
Nurul Fauziah ${ }^{1}$, Ansariadi Ansariadi ${ }^{1}$, Darmawansyah Darmawansyah ${ }^{2}$, M. Wahidin ${ }^{1,3}$, Reski Amaliah ${ }^{1,4}$, Zhanaz Tasya $^{1,4}$, \\ Itma Annah ${ }^{1,5}$, Iva Hardi Yanti ${ }^{1 *}$ \\ ${ }^{1}$ Department of Epidemiology, Faculty of Public Health, Hasanuddin University, Makassar, Indonesia; ${ }^{2}$ Department of Health \\ Administration and Policy, Faculty of Public Health, Hasanuddin University, Makassar, Indonesia; ${ }^{3}$ Majene Health Office, \\ Majene Regency, West Sulawesi, Indonesia; ${ }^{4}$ Jeneponto Health Office, Jeneponto Regency, South Sulawesi, Indonesia; \\ ${ }^{5}$ Health Polytechnic of Palangkaraya, Central Kalimantan, Indonesia
}

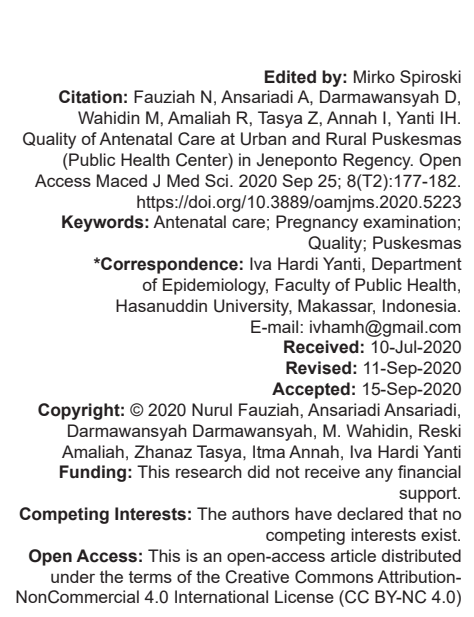

\section{Introduction}

Increasing the quality of service coverage must be done to reduce maternal mortality, in Tanzania 94\% of women make ANC visits and $54 \%$ do so with four visits. However, this is precisely in line with the increase in maternal mortality [1]. This shows that the quantity of coverage does not fully indicate the quality of service. In India, national survey results show that incentive programs for mothers and health institution workers as an increase in service coverage [2], [3]. This has not been matched by efforts to monitor and improve the quality of childbirth services so that it impacts on the unclear survival of mothers and babies [4].

Based on the previous exposure, it is known that improving health services have not been able to reduce maternal mortality rates so that adequate intervention is needed. There are two interventions that can be done in reducing the mortality rate, namely, antenatal care (ANC) and intrapartum services (labor and birth). The essence of the ANC is preparing births for women and making them parents, preventing problems in women, pregnant women, and infants with early detection, eradication, and management of problems that affect the mother and baby during pregnancy [5]. Inadequate ANC services, both coverage and quality, will result in poor pregnancy outcomes [6].

Utilization of ANC services varies between countries based on the lack of utilization of ANC services in pregnant women in Asian and African countries with low incomes [7]. In a country, utilization of ANC services differs in maternal age, education, employment, family income, parity, residence, costs, and availability of health facilities [8], [9], [10], [11]. Based on the region of residence, several studies show that urban women visit ANC more often than rural women. Research conducted by Fekadu and Regassa [12] looked at the quality of ANC utilization programs in Ethiopia describing $15.6 \%$ of mothers living in urban areas receiving good services compared to in rural areas only $4.5 \%$ of mothers receiving good service quality due to 
lack of skilled health workers. Other research shows that there is no difference in the use of ANC services in urban and rural areas [13], [14].

In Indonesia, pregnant women can obtain ANC services in various health facilities, namely, Puskesmas, Posyandu/Polindes, Hospitals, Maternity Homes, Doctors/Clinical Practices, and midwives practice [15]. Health facilities are provided to increase the coverage of maternal health services. Based on the Republic of Indonesia Ministry of Health's Report (2013), almost all pregnant women in Indonesia (95.4\%) had already pregnancy check (K1) and the frequency of pregnancy at least 4 times during her pregnancy was $83.5 \%$. The coverage of the first pregnancy check-up in the first trimester is $81.6 \%$ and the ANC frequency is $1-1-2$ or K4 (at least 1 time in the first trimester, at least 1 time in the second trimester, and at least 2 times in the third trimester) by $70.4 \%$. However, this shows that the high coverage has not yet fully demonstrated the quality of ANC services.

Based on the results of the Riskesdas of South Sulawesi [16] Puskesmas/Pustu were the most visited places for pregnant women during ANC (51.1\%), practice midwives (17.4\%), and Poskesdes/Polindes $(10.6 \%)$. Puskesmas categories by region are divided into puskesmas in urban areas, rural areas, and remote and very remote areas (Permenkes RI No. 75, 2014). In Jeneponto, puskesmas only consist of puskesmas in urban and rural areas. Urban health centers include Binamu Health Centers, City Binamu Health Centers, and City Bontosunggu Health Centers. Rural health centers include Bontomate'ne Puskesmas, Bululoe Puskesmas, Tamatea Puskesmas, Bontoramba Puskesmas, Bangkala Puskesmas, Kapita Puskesmas, Buludoang Puskesmas, Barana Puskesmas, Torana Puskesmas, Toro-Toro Puskesmas, Barana Puskesmas, Tino Puskesmas, Arungkeke Puskesmas, Kapita Puskesmas, Buludoang Puskesmas, Barana Puskesmas, Toro-Toro Puskesmas, Barana Puskesmas, Toba Puskesmas, Arungkeke Puskesmas, Arungkeke Puskesmas, Tolo Puskesmas, Barolo Puskesmas, Barolo Puskesmas, Tolo Puskesmas, Puskesmas Tompo Bulu, and Puskesmas Rumbia.

Jeneponto is one of the areas in South Sulawesi which is a health problem area (Riskesdas, 2014). In the last 3 years, the trend of maternal mortality has fluctuated, successively from 2013 to 2015 with figures of 170,235 , and 170/100,000 live births, DEPES Jeneponto, 2015). However, this is inversely proportional to the coverage data $\mathrm{K} 1$ and $\mathrm{K} 4$ which are quite good. In 2013, k1 and k4 coverage, coverage of deliveries assisted by Nakes was $97.6 \%, 89.8 \%$, and $88.6 \%$, respectively. In 2014, k1 and k4 coverage, coverage of deliveries assisted by Nakes was $97.8 \%$, $84.7 \%$, and $86.6 \%$ whereas in 2015 , coverage of $k 1$ and $\mathrm{k} 4$, coverage of deliveries assisted by Nakes, respectively, $100.4 \%, 87.0 \%$, and $96.2 \%$ (DEPES Jeneponto, 2015). Seeing this, further investigation is needed regarding the quality of ANC services in Jeneponto Regency.

\section{Materials and Methods}

This research was carried out in the Jenponto District Health Centers. This type of research is observational analytic with cross-sectional design. The population in this study was pregnant women visiting the puskesmas from October 2015 to May 2016, as many as 4156 pregnant women. The puskesmas included in this study were randomly selected where out of the eighteen puskesmas in Jeneponto there were three urban puskesmas and 15 rural puskesmas.

The selected urban area health centers are Binamu City Health Centers and Binamu City Health Centers, while the selected rural area health centers are the Bonto Matene Health Center and the Bonto Ramba Health Center. The sample in this study was pregnant women who visited to use ANC services in the Jeneponto health center and met the inclusion and exclusion criteria. Based on the sample calculation above, the total sample of each puskesmas in rural and urban areas is 139 pregnant women and the total sample is 278 pregnant women. The number of samples drawn from each puskesmas was carried out using stratified random sampling technique. Secondary data were obtained from data on visits of pregnant women from the Jeneponto District Office recapitulation. Primary data obtained from direct observations in the field. Data analysis was performed using the SPSS program and statistical tests using bivariate tests.

\section{Results}

The results showed that the majority (29\%) of respondents were in the 20-24 years group, following the 25-29 years age group, and the smallest were in the $\geq 40$ years group. Based on education, half of the respondents $(48 \%)$ only completed elementary school education (48\%), there were $26 \%$ respondents who completed high school education, while the least were respondents who graduated from college. Based on gestational age, most respondents were in the third trimester of pregnancy (49.35), and then those in the second trimester $(38.5 \%)$ and the least were respondents in the first trimester (12.2\%) (Table 1).

The quality assessment in this study was divided into good quality, minimum quality, and lack of quality (Table 2). The results showed that the highest percentage was in rural health centers with the category of poor quality as many as 95 respondents (65.1\%). 
Table 1: Distribution of respondents based on characteristics

\begin{tabular}{lll}
\hline Karakteristik & Frekuensi & $\%$ \\
\hline Age (Year) & 32 & \\
$\leq 19$ & 79 & 11 \\
$20-24$ & 65 & 29 \\
$25-29$ & 44 & 23 \\
$30-34$ & 47 & 16 \\
$35-39$ & 11 & 17 \\
$\geq 40$ & & 4 \\
Education & 24 & 9 \\
$\quad$ Not completed in primary school & 132 & 48 \\
Graduated from elementary school & 40 & 14 \\
Graduated from middle school & 73 & 26 \\
Graduated from high school & 9 & 3 \\
$\quad$ Graduated from college & & \\
Gestational age & 34 & 12.2 \\
$\quad$ Trimester I & 107 & 38.5 \\
Trimester II & 137 & 49.3 \\
Trimester III & & \\
\hline
\end{tabular}

For the minimum quality category, the quality of ANC in urban health centers $(66.7 \%)$ is higher than in rural areas $(33.3 \%)$. Statistical test results showed that there were differences in ANC quality based on rural and urban health centers $(p=0.000)$.

Table 2: Antenatal care quality analysis based on Puskesmas in rural and urban areas in Jeneponto regency

\begin{tabular}{|c|c|c|c|c|c|c|c|}
\hline \multirow[t]{2}{*}{ Quality of ANC } & \multicolumn{2}{|c|}{$\begin{array}{l}\text { Puskesmas in } \\
\text { Urban }\end{array}$} & \multicolumn{2}{|c|}{$\begin{array}{l}\text { Puskesmas in } \\
\text { Rural }\end{array}$} & \multicolumn{2}{|c|}{ Total } & \multirow[t]{2}{*}{$p$-value } \\
\hline & $\mathrm{n}$ & $\%$ & $\mathrm{n}$ & $\%$ & $n$ & $\%$ & \\
\hline Good quality & 6 & 33.3 & 12 & 66.7 & 18 & 100 & 0.000 \\
\hline Minimum quality & 38 & 33.3 & 76 & 66.7 & 114 & 100 & \\
\hline Low Quality & 95 & 65.1 & 51 & 34.9 & 146 & 100 & \\
\hline
\end{tabular}

In this study, the components of pregnancy examination consisted of 11 components, namely, height measurement, weight measurement, nutritional status assessment (LILA), fundal height measurement, blood pressure measurement, fetal presentation, examination of fetal heart rate, giving TT immunization, giving FE tablets, and examination of blood type and hemoglobin (Table 3). The results showed that of the 11 components, there were three components that showed differences in rural and urban health centers, namely, weight measurement, fundal height measurement, and FE tablet administration. As for the components of height measurement, the assessment of nutritional status (MUAC), fetal presentation, examination of fetal heart rate, administration of TT immunization, and examination of blood type and hemoglobin. The component of blood pressure measurement was not included in the statistical test because all respondents received the examination.

Respondents who did not get the highest height measurement services were in the Community Health Center in 104 people (53.9\%). Statistical test results showed that there was no difference in ANC quality based on height measurements in rural and urban health centers $(p=0068)$. Respondents who received the highest weight measurement services were in the Community Health Center as many as 104 people (54.5\%). Statistical test results showed that there were differences in ANC quality based on weight measurements in rural and urban health centers $(p=0.038)$. Respondents who did not get the
Table 3: ANC quality difference analysis based on pregnancy examination components in Jeneponto District and rural health centers

\begin{tabular}{|c|c|c|c|c|c|c|c|}
\hline \multirow[t]{2}{*}{ Components of pregnancy checking } & \multicolumn{2}{|c|}{$\begin{array}{l}\text { Puskesmas } \\
\text { in urban }\end{array}$} & \multicolumn{2}{|c|}{$\begin{array}{l}\text { Puskesmas } \\
\text { in rural }\end{array}$} & \multicolumn{2}{|c|}{ Total } & \multirow[t]{2}{*}{ p-value } \\
\hline & $\mathrm{n}$ & $\%$ & $\mathrm{n}$ & $\%$ & $\mathrm{n}$ & $\%$ & \\
\hline \multicolumn{8}{|l|}{ Height measurement } \\
\hline Yes & 50 & 58.8 & 35 & 41.1 & 85 & 100 & \multirow[t]{2}{*}{0.068} \\
\hline No & 89 & 46.1 & 104 & 53.9 & 193 & 100 & \\
\hline \multicolumn{8}{|l|}{ Weight measurement } \\
\hline Yes & 104 & 54.5 & 87 & 45.5 & 191 & 100 & \multirow[t]{2}{*}{0.038} \\
\hline No & 35 & 40.2 & 52 & 59.8 & 87 & 100 & \\
\hline \multicolumn{8}{|l|}{ LILA measurement } \\
\hline Yes & 41 & 53.9 & 35 & 46.1 & 76 & 100 & \multirow[t]{2}{*}{0.501} \\
\hline No & 98 & 48.5 & 104 & 51.5 & 202 & 100 & \\
\hline \multicolumn{8}{|l|}{ Uterine fundus height measurement } \\
\hline Yes & 125 & 53 & 111 & 47 & 236 & 100 & \multirow[t]{2}{*}{0.029} \\
\hline No & 14 & 33.3 & 28 & 66.7 & 42 & 100 & \\
\hline \multicolumn{8}{|l|}{ Blood pressure measurement } \\
\hline Yes & 139 & 50.0 & 139 & 50.0 & 278 & 100 & \multirow[t]{2}{*}{ - } \\
\hline No & 0 & 0 & 0 & 0 & 0 & 100 & \\
\hline \multicolumn{8}{|l|}{ Fetus presentation } \\
\hline Yes & 95 & 50.3 & 94 & 49.7 & 189 & 100 & \multirow[t]{2}{*}{1.000} \\
\hline No & 44 & 49.4 & 45 & 50.6 & 89 & 100 & \\
\hline \multicolumn{8}{|l|}{ Fetal heart rate examination } \\
\hline Yes & 95 & 50.3 & 94 & 49.7 & 189 & 100 & \multirow[t]{2}{*}{1.000} \\
\hline No & 44 & 49.4 & 45 & 50.6 & 89 & 100 & \\
\hline \multicolumn{8}{|l|}{ Tetanus immunization } \\
\hline Yes & 52 & 53.1 & 46 & 46.9 & 98 & 100 & \multirow[t]{2}{*}{0.530} \\
\hline No & 87 & 48.3 & 93 & 51.7 & 180 & 100 & \\
\hline \multicolumn{8}{|l|}{ Provision of FE tablets } \\
\hline Yes & 87 & 44.4 & 109 & 55.6 & 196 & 100 & \multirow[t]{2}{*}{0.006} \\
\hline No & 52 & 63.4 & 30 & 36.6 & 82 & 100 & \\
\hline \multicolumn{8}{|l|}{ Blood type examination } \\
\hline Yes & 12 & 70.6 & 5 & 29.4 & 17 & 100 & \multirow[t]{2}{*}{0.133} \\
\hline No & 127 & 48.7 & 134 & 51.3 & 261 & 100 & \\
\hline \multicolumn{8}{|l|}{ Inspection of $\mathrm{Hb}$} \\
\hline Yes & 46 & 45.1 & 56 & 54.9 & 102 & 100 & \multirow[t]{2}{*}{0.263} \\
\hline No & 93 & 52.8 & 83 & 47.2 & 176 & 100 & \\
\hline
\end{tabular}

highest nutritional status measurement (LILA) service were in the Community Health Center in 104 people $(51.5 \%)$. Statistical test results showed that there was no difference in ANC quality based on height measurements in rural and urban health centers ( $p=0.501)$ (Table 3).

Respondents who received the highest fundus uteri height measurement services were in the Community Health Center as many as 125 people (53\%). Statistical test results showed that there was a difference in ANC quality based on the measurement of uterine fundus height in rural and urban health centers $(p=0.029)$. Respondents who received fetal presentation services as well as examining the highest fetal heart rate were in the Community Health Center in 95 people (50.3\%). Statistical test results showed that there was no difference in ANC quality based on fetal presentation in rural and urban health centers (Table 3).

Respondents who received the highest $\mathrm{FE}$ tablet delivery services were in the Community Health Center in 109 people (55.6\%). Statistical test results showed that there were differences in ANC quality based on FE tablets in rural and urban health centers $(p=0.006)$. Respondents who did not get the highest blood type examination services were in the Community Health Center in 127 people (51.3\%). Statistical test results showed that there was no difference in the quality of the ANC based on blood type examination in rural and urban health centers $(p=0.133)$. Respondents who did not get the highest blood type examination 
services were in the Community Health Center in 127 people $(51.3 \%)$. Statistical test results showed that there was no difference in the quality of ANCs based on blood type examinations in puskesmas in rural and urban areas $(p=0.133)$ (Table 3$)$.

\section{Discussion}

This study found that $52 \%$ of pregnant women received poor ANC in Jeneponto District, 51\% received minimum ANC, and only $6.4 \%$ received good ANC. Poor quality of ANC for pregnant women assumes that getting a pregnancy check under six components based on gestational age, is said to be of minimum quality if the mother gets seven or eight components, and is said to be of good quality if all components of ANC are fulfilled according to the gestational age. Ideally, pregnant women receive minimum ANC based on their gestational age. However, this study found that the percentage of pregnant women who received minimum and bad services was almost the same.

The high percentage of pregnant women who receive poor quality services is due to some components of the examination that was not given to pregnant women at the time of the examination at the puskesmas and there was a statement from the official that the component was not provided on the grounds that the regent stock was depleted.

Based on the 11 components of ANC that was linked in this study, only three components showed that there were differences in the provision of the examination components in puskesmas in rural and urban areas. The three components are weight, fundal height, and FE tablets.

Body weight measurements should ideally be given at each pregnancy check-up visit. However, this study found that weight measurements at rural health centers were better than urban health centers. This means that the distribution of weight measurement components is uneven in Jeneponto Regency. Based on field observations related to body weight measurements, the tools used during pregnancy checks in all puskesmas use manual body scales. The result of the interview with the midwife in charge stated that the scales were a division tool from the center and they did not pay attention to the effectiveness of the tools.

The study also found that there were differences in the provision of FE tablets in rural and urban health centers. The results of the same study conducted in Nigeria Ajayi [17] found that there were differences in the administration of FE tablets in villages and cities. In this study, administration of FE tablets was higher in urban health centers than in rural health centers. Ideally, pregnant women get 90 tablets during pregnancy. However, in this study, as many as, $30 \%$ of respondents did not get FE tablets. The results of interviews with health workers stated that the FE tablet was adjusted to the condition of pregnant women when visiting the health center. If pregnant women come with a yellow/pale face, with complaints of nausea/vomiting in trimesters II and III, then given a 10-strip FE tablet. Besides, the provision of FE tablets also adjusted to the presence or absence of logistics available at the time although FE tablets should be given from the first contact with pregnant women and given at least 90 tablets during pregnancy. The administration of FE tablets is different for each gestational age, that is, $1000 \mathrm{mg}$ during a total pregnancy. The need for iron in trimesters II and III cannot be fulfilled from food alone, although the food eaten is of good quality and high bioavailability of iron, but iron must also be supplied from other sources to be sufficient. Giving FE tablets to pregnant women can reduce the proportion of anemia because it increases hemoglobin in the blood up to $0.7 \mathrm{~g} / \mathrm{dl}$ every week [18].

This study found that in both rural and urban health centers, height measurements had no difference. This is because the tendency for height checks is only done during the first visit of pregnant women at the puskesmas. The results of interviews with health workers stated that because their height did not change in the near term so they only did height checks at the first visit of the pregnant women both at the time of the mothers with gestational age trimester II and trimester III. This is in accordance with the provisions Ministry of Health RI [19] that height measurements are only carried out at the first visit of pregnant women.

Similar to height measurement, this study found that the measurement of nutritional status (LILA) in both rural and urban health centers did not have a difference. This is because the measurement of LILA is only done at the first visit of pregnant women, while the number of respondents in this study was mostly in the second and third trimester of pregnancy (87.8\%). The results of the study by Ververs [20] show that measurement of MUAC in pregnant women is an indicator of protein-nutrient deficiency, especially if height and weight measurements are not carried out.

Blood pressure is a component of the examination carried out $100 \%$ both in rural and urban health centers so that there is no bivariate analysis. This shows that the most routine component in the puskesmas is a blood pressure check. The results of the same study conducted in Nigeria by Fagbamigbe and Idemudia [2] and in Tanzania by Sarker [21] that blood pressure testing is the most frequent component of ANC for pregnant women (91\%). If related to the use of tools that are in accordance with the standards, there is one health center that does not use blood pressure measuring instruments with mercury indicators.

Examination of uterine fundus height, fetal heart rate and fetal presentation are examinations of 
the abdomen in pregnant women. In this study found that examination of fundal uterine height in rural and urban health centers had differences, while examination of fetal heart rate and fetal presentation did not have differences in the two regions. The difference in the two regions in the examination of the fundus uteri height is due to the highest examination in puskesmas in rural areas. The results of a different study conducted by Ajayi [17] found that abdominal examination in pregnant women did not have a difference either in the village or in the city. However, the abdominal examination in the study included the three examinations of uterine fundus height, MUAC, and height not by differentiating between examinations. There is no difference in examination of fetal presentation and fetal heart rate in the two regions because most examinations are performed starting at the end of the second trimester. The official stated that in general the fetal heart rate can only be felt at 20 weeks gestation.

Tetanus toxoid administration was also included in the component that had no difference in both rural and urban health centers found in this study. The absence of this difference is due to the tendency of this examination to be varied at each gestational age of pregnant women. In this case adjusted for the interval of TT immunization. However, if the pregnant woman forgets the last time she did the TT immunization, and then the immunization will be repeated to TT1. The results of a different study conducted by Ajayi [17] found that there were differences in the administration of TT injections in villages and cities in Nigeria. Giving TT injections is higher than in cities.

In this study, laboratory examination only included two tests, namely, examination of hemoglobin blood type. Both are examination components that have no difference in both rural and urban health centers. Blood type examination is the component of the examination that is most rarely given to pregnant women. This is because most pregnant women already know their blood type and the existence of a health center that does not provide these components.

Hemoglobin examination in rural and urban health centers is done if pregnant women come with an indication that the face is pale/yellowing so that during observation, not all pregnant women are given these components. The results of a different study conducted in Nigeria by Ajayi [17] found that there were differences in hemoglobin examinations in rural and urban areas where examinations in urban areas were more adequate and complete.

A smaller decrease in hemoglobin level during pregnancy from early to mid-pregnancy or at the end of pregnancy is associated with LBW infants, Z-score birth weight, placental weight, and placental ratio [22] Decreased hemoglobin in the blood causes anemia in pregnant women. Severe anemia from early pregnancy is also associated with poor birth, for example, LBW [23].

\section{Recommendation}

There is a need for equitable delivery of components of ANC in both rural and urban health centers by providing training and knowledge about ANC to midwives concerned.

\section{References}

1. Tanzania National Bureau of Statistics. Tanzania Demographic and Health Survey 2004. Australia: Tanzania National Bureau of Statistics; 2005.

2. Fagbamigbe A, Idemudia E. Assessment of quality of antenata care services in Nigeria: Evidence from a population-based survey. Reprod Health. 2015;12:88. https://doi.org/10.1186/ s12978-015-0081-0

PMid:26382228

3. Lim S, Dandona L, Hoisington JA, James SL, Hogan MC, Gakidou E. India's Janani Suraksha Yojana, a conditional cash transfer programme to increase births in health facilities: An impact evaluation. Lancet. 2010;375:2009-23. https://doi. org/10.1016/s0140-6736(10)60744-1

PMid:20569841

4. UN Population Fund India. Concurrent Assessment of Janan Suraksha Yojana (JSY) in Selected States. India: UN Population Fund India; 2009.

5. Lincetto $\mathrm{O}$, et al. Antenatal Care: Opportunities For Africa's Newborns. New York: World Health Organiation; 2010.

6. Titaley C, Dibley MJ, Roberts CL. Factors associated with underutilization of antenatal care services in Indonesia: Results of Indonesia demographic and health survey 2002/2003 and 2007. BMC Public Health. 2010;10:485. https://doi. org/10.1186/1471-2458-10-485

PMid:20712866

7. Zanconato G, Msolomba R, Guarenti L, Franchi M. Antenata care in developing countries: The need for a tailored model: Semin fetal neonatal med 2006. Semin Fetal Neonatal Med. 2006;11(1):15-20. https://doi.org/10.1016/j.siny.2005.10.002 PMid: 16364704

8. Birmeta K, Dibaba Y, Woldeyohannes D. Determinants of maternal health care utilization in holeta Town, Central Ethiopia. BMC Health Serv Res. 2013;13:256. https://doi. org/10.1186/1472-6963-13-256

9. Celik Y. The socio-economic determinants of alternative sources of antenatal care in Turkey. Int J Health Plan Manag. 2000;13:1-10.

10. Ejigu T, Woldie M, Kifle Y. Quality of antenatal care services at public health facilities of bahir-dar special zone, Northwest Ethiopia. BMC Health Serv Res. 2013;13:443. https://doi. org/10.1186/1472-6963-13-443

11. Kyei N, Chansa C, Gabrysch S. Quality of antenatal care in Zambia: A national assessment. BMC Pregnancy Childbirth. 2012;12(151):1-11. https://doi.org/10.1186/1471-2393-12-151

12. Fekadu M, Regassa N. Skilled delivery care service utilization in Ethiopia: Analysis of rural-urban differentials based on national demographic and health survey (DHS) data. Afr Health Sci. 2014;14(4):974-84. https://doi.org/10.4314/ahs.v14i4.29 PMid:25834510

13. Say L, Raine R. A systematic review of inequalities in the use of maternal health care in developing countries: Examining the scale of the problem and the importance of context. Bull World Health 
Organ. 2007;85(10):811-19. https://doi.org/10.2471/blt.06.035659 PMid: 18038064

14. Simkhada B, van Teijlingen ER, Porter M, Simkhada P. Factors affecting the utilization of antenatal care in developing countries: Systematic review of the literature.JAdv Nurs. 2008;61(3):244-60. https://doi.org/10.1111/j.1365-2648.2007.04532.x PMid: 18197860

15. Kemenkes RI. Riset Kesehatan Dasar. Jakarta: Ministry of Health; 2013

16. Riskesdas. Riset Kesehatan Dasar. Jakarta: Ministry of Health; 2014.

17. Ajayi I, Osakinle DC, Osakinle EO. Quality assesment of the practice of focused antenatal care (FANC) in rural and urban primary health centres in Ekiti state. J Obstetrics Gynecol. 2013;3:319-26. https://doi.org/10.4236/ojog.2013.33059

18. Dowswell T, Carroli G, Duley L, Gates S, Gülmezoglu AM, Khan-Neelofur D, et al. Alternative versus standard packages of antenatal care for low-risk pregnancy. Eur PMC Funders Group. 2010;4:1-76.

19. Kemenkes RI. Pedoman Pelayanan Antenatal Terpadu. Jakarta: Ministry of Health; 2015.
20. Ververs M, Antierens A, Sackl A, Staderini N, Captier V. Which anthropometric indicators identify a pregnant woman as acutely malnourished and predict adverse birth outcomes in the humanitarian context. PLos One. 2013;2:1-15. https://doi. org/10.1371/currents.dis.54a8b618c1bc031ea140e3f2934599c8 PMid:23787989

21. Sarker M, Schmid G, Larsson E, Kirenga S, De Allegri M, Neuhann F, et al. Quality of antenatal care in Rural Southern Tanzania: A reality check. BMC Health. 2010;3:209. PMid:20663202

22. Jwa S, Fujiwara T, Yamanobe $Y$, Kozuka K, Sago H. Changes in maternal hemoglobin during pregnancy and birth outcomes. BMC Pregnancy Childbirth. 2015;15:80. https://doi.org/10.1186/ s12884-015-0516-1

PMid:25884586

23. Bakacak M, Avci F, Ercan O, Köstü B, Serin S, Kiran G, et al. The effect of maternal hemoglobin concentration on fetal birth weight according to trimesters. J Matern Fetal Neonatal Med.2004;28(17):2106-10. https://doi.org/10.3109/14767058.2 014.979149

PMid:25338012 